\title{
Atividade fitotóxica de Croton doctoris S. Moore
}

\author{
Phytotoxic activity of Croton doctoris S. Moore
}

\author{
Ana Carina da Silva Cândido ${ }^{I^{*}}$ Cristiane Bezerra da Silva $^{\text {II }}$ Euclesio Simionatto $^{\text {II }}$ \\ Daisa BigatonI Silvana de Paula Quintão Scalon' ${ }^{\mathrm{I}}$ Marize Teresinha Lopes Pereira Peres ${ }^{\mathrm{II}}$
}

\section{RESUMO}

O objetivo deste trabalho foi caracterizar o efeito fitotóxico do extrato etanólico bruto e frações semipurificadas do caule e folhas de $\boldsymbol{C}$. doctoris na germinação, crescimento inicial e divisão celular das células radiculares de alface (Lactuca sativa) $e$ cebola (Allium cepa), em laboratório. O experimento foi realizado em delineamento inteiramente casualizado, sendo utilizadas quatro concentrações dos tratamentos $\left(0,250,500,1.000 \mathrm{mg} \mathrm{L}^{-1}\right)$, com quatro repetições. $O$ extrato bruto e as frações do caule e folhas inibiram a germinação e crescimento de alface e cebola, sendo o maior efeito fitotóxico promovido pela fração acetato de etila (FAE) do caule e folhas que afetou significativamente o crescimento e índice mitótico das células radiculares de alface e cebola. Com os resultados obtidos, verifica-se que a espécie C. doctoris apresenta substâncias capazes de influenciar no crescimento e divisão celular das espécies avaliadas.

Palavras-chave: aleloquímicos, inibição do crescimento, mitose.

\section{ABSTRACT}

The aim of this study was to verify the phytotoxic effect of the crude ethanol extract and semipurified fractions from the stem and leaves of Croton doctoris on the germination, growth and cell division of roots cells of lettuce (Lactuca sativa) and onion (Allium cepa), in the laboratory. The bioassays was conducted in using completely randomized design, with four concentrations $(0$, $\left.250,500,1.000 \mathrm{mg}^{-1}\right)$ and four replications. The crude extract and the fractions from the stem and leaves inhibited germination and seedling growth of lettuce and onion, with greater phytotoxic effect observed in the ethyl acetate fraction $(E A F)$ from the stems and leaves that significantly affected the growth and mitotic index of root cells of lettuce and onions. With these results it appears that $\boldsymbol{C}$. doctoris contains substances capable of influencing the germination, growth and cell division of the species studied.

Key words: allelochemicals, growth inhibition, mitosis.

\section{INTRODUÇÃO}

Estudos alelopáticos têm avaliado a ação de diversos extratos e princípios ativos, extraídos de material vegetal e, posteriormente, sintetizados, sobre o controle de plantas daninhas (MACIAS et al., 2000a; BARBOSA et al., 2002). O controle de espécies daninhas, mediante a aplicação de aleloquímicos, pode ter uma importância estratégica pela sua atuação seletiva e pelo baixo poder residual (RIZVI et al., 1999).

O gênero Croton (Euphorbiaceae) compreende cerca de 1.300 espécies, amplamente distribuídas em todas as regiões do Brasil. Várias espécies do gênero, há muito tempo, desempenham papel importante nos usos tradicionais de plantas medicinais na África, Ásia e América do Sul (SALATINO et al., 2007). Croton doctoris S. Moore (Euphorbiaceae) (Croton: carrapato, semente; doctoris: doutor, medicinal), conhecida popularmente por amarelinho do pantanal, é uma planta nativa da floresta decidual calcária e do Chaco, tem preferência por solos pesados e férteis, sendo frequentemente encontrada na região de Porto Murtinho, Estado de Mato Grosso do Sul (MS), Brasil. É uma invasora nova que está aumentando na microrregião de Porto Murtinho (MS), onde se tornou uma das piores infestantes, formando conjuntos densos. Também ocorre em Corumbá (MS) e um pouco no Pantanal, em Paconé no Estado de Mato Grosso (MT), Brasil

${ }^{\mathrm{I}}$ Departamento de Ciências Agrárias, Universidade Federal da Grande Dourados (UFGD), Rodovia Dourados-Itahum, Km 12, CP 533, Cidade Universitária, 79804-970, Dourados, MS, Brasil. E-mail: carinacandido@ hotmail.com. *Autor para correspondência.

${ }^{\text {II }}$ Centro de Ciências Exatas e Tecnologia, Universidade Federal de Mato Grosso do Sul (UFMS), Campo Grande, MS, Brasil. 
(POTT et al., 2007). Segundo POTT et al (2007), aparentemente, Croton doctoris apresenta efeito alelopático sobre gramíneas, que ficam ralas embaixo da planta. Na literatura, nenhum estudo quanto ao perfil químico, biológico e alelopático dessa espécie foram investigados.

Diante disso, o objetivo do presente trabalho foi avaliar a atividade fitotóxica do extrato etanólico bruto e frações semipurificadas do caule e folhas de $\boldsymbol{C}$. doctoris sobre a germinação, crescimento e índice mitótico de alface (Lactuca sativa) e cebola (Allium cepa) em laboratório.

\section{MATERIAL E MÉTODOS}

Croton doctoris foi coletada em fevereiro de 2008 no município de Porto Murtinho, Estado de Mato Grosso do Sul (MS), Brasil, nas seguintes coordenadas geográficas $21^{\circ} 48^{`} 37,8^{\prime \prime} \mathrm{S}$ e $57^{\circ} 43^{`} 31,5^{\prime}$ " W. Uma exsicata da espécie foi depositada no Herbário da Universidade Federal de Mato Grosso do Sul (UFMS) em Campo Grande (MS), Brasil, sob $\mathrm{n}^{\mathrm{o}}$ de registro 20.164. A espécie encontravase em fase de florescimento. Após a coleta, a parte aérea (caule, folhas e flores) foi separada e reduzida a pequenos fragmentos. A matéria fresca teve sua massa registrada e foi acondicionada em saco plástico a $-7^{\circ} \mathrm{C}$, até sua utilização.

Para o preparo do extrato etanólico bruto (EEB), o caule e as folhas frescas de $\boldsymbol{C}$. doctoris foram submetidos à extração por meio de maceração com etanol $(\mathrm{m} / \mathrm{v}, 1: 2)$. O solvente foi evaporado $\left( \pm 40^{\circ} \mathrm{C}\right)$ sob vácuo em evaporador rotativo, obtendose o extrato etanólico bruto do caule (EEBC) $(10 \mathrm{~g})$ e folhas (EEBF) (30g) de $\boldsymbol{C}$. doctoris.

Para a obtenção das frações semipurificadas (FS), o EEBC e EEBF foram fracionados através do processo de partição líquido-líquido com solventes de polaridade crescente, hexano e acetato de etila, em funil de decantação, visando a uma semipurificação das substâncias através da sua polaridade. Sendo obtidas as frações: hexânica $(\mathrm{FH})(2,5 \mathrm{~g})$, acetato de etila (FAE) $(2,8 \mathrm{~g})$ e etanol-água (FEA) (4g).

Para a avaliação da atividade alelopática da espécie em estudo, utilizou-se bioensaio biomonitorado com espécies alvo sensíveis para identificação do tratamento com maior fitotoxicidade (MACIAS et al., 2000b). Nos bioensaios, o EEB e FS do caule e folhas de $\boldsymbol{C}$. doctoris foram avaliados sobre a germinação, crescimento e índice mitótico das espécies alvo de alface (Lactuca sativa L. cv. 'Grand rapids') e cebola (Alium cepa L. cv. 'Baia Periforme'). Para os bioensaios, solução-estoque na concentração de $1.000 \mathrm{mg} \mathrm{L}^{-1}$ foi preparada a partir da massa calculada para cada EEB e FS, as quais foram dissolvidas em DMSO (Dimetilsulfóxido) a 0,1\% (DAYAN et al., 2000), sendo as concentrações de 500 e $250 \mathrm{mg} \mathrm{L}^{-1}$ preparadas por diluição. As soluções foram tamponadas com solução de MES (Ácido 2-morfolinoetanosulfônico) 10mM (MACIAS et al., 2000b), e o pH foi ajustado para 6,0 (MACIAS et al., 2000b) com solução de KOH 0,1N. Como controle, preparou-se uma solução com DMSO a $0,1 \%$, a qual também foi tamponada com MES (10mM).

Para os bioensaios de germinação, as placas de Petri contendo papel filtro receberam $5,0 \mathrm{~mL}$ da solução dos tratamentos (MACIAS et al., 2000b). Em seguida, semearam-se 50 sementes da espécie-alvo (alface e cebola), distribuídas aleatoriamente, com quatro repetições para cada solução (BRASIL, 2009). As placas de Petri foram levadas a uma câmara de germinação (BOD), com condições de luz (160W), umidade relativa $( \pm 80 \%)$ e temperatura constante, adequadas a cada espéciealvo (BRASIL, 2009). A contagem para avaliar a germinação foi realizada diariamente, tendo como critério a protrusão radicular com no mínimo $2,0 \mathrm{~mm}$ de comprimento (BRASIL, 2009). O experimento foi considerado concluído quando a germinação foi nula por três dias consecutivos.

Para os bioensaios de crescimento e avaliação do índice mitótico, primeiramente as sementes foram pré-germinadas em placas de Petri umedecidas com água destilada. Após a germinação, foram selecionadas 80 plântulas (quatro repetições de 20), para cada tratamento, as quais foram transferidas para placas de Petri contendo as soluções tratamento, utilizando-se procedimento similar ao descrito nos bioensaios de germinação (MACIAS et al., 2000b). A leitura dos parâmetros avaliados foi realizada após quatro dias da incubação.

Para a determinação do índice mitótico, foram coletados de cada plântula dois centímetros da raiz primária, a partir da extremidade distal, e imersos em fixador de Farmer (3:1, etanol: ácido acético glacial), durante duas horas, a $25^{\circ} \mathrm{C}$ e, em seguida, foram transferidos para uma solução de álcool 70\% e armazenados a $8^{\circ} \mathrm{C}$. Para determinação do índice mitótico, as pontas de raízes foram tratadas na seguinte ordem: 1) água destilada por cinco minutos; 2) ácido clorídrico $1 \mathrm{M}$ por 30 minutos a temperatura ambiente; 3) água destilada por cinco minutos e 4) orceina acética $2 \%$ por 30 minutos. As pontas das raízes coradas tiveram o ápice, 2,0mm iniciais, cortados sobre lâmina de microscópio, colocandose, em seguida, a lamínula e pressionando sob esta o 
papel de filtro para esmagamento do ápice e retirada do excesso de corante. O material foi observado em microscópio ótico comum, com aumento de 1000X, contando-se o número de células em cada fase da mitose (prófase, metáfase, anáfase e telófase). Para cada tratamento, foram preparadas três lâminas, avaliando-se três campos/lâmina. O índice mitótico foi obtido dividindo-se o número de células em mitose (prófase + metáfase + anáfase + telófase) pelo número total de células (interfase + mitose) multiplicando-se por 100 (PIRES et al., 2001).

$\mathrm{O}$ delineamento experimental foi $\mathrm{o}$ inteiramente casualizado, com quatro repetições para germinação e crescimento e três repetições para o índice mitótico. A partir dos resultados das análises de variância (ANOVA), as médias foram comparadas pelo teste de Tukey, a 5\% de probabilidade, e os resultados submetidos à análise de regressão.

\section{RESULTADOS E DISCUSSÃO}

Com base nos resultados obtidos, observaram-se as menores porcentagens de germinação e reduções do índice de velocidade de germinação (IVG) pela fração acetato de etila do caule (FAEC) e das folhas (FAEF) em alface e extrato etanólico bruto do caule (EEBC), folhas (EEBF), FAEC e FAEF em cebola. Isso pode ser evidenciado devido aos maiores IVG e porcentagens de germinação serem observados no tratamento controle, que apresentava a mesma composição dos outros tratamentos, porém com ausência dos extratos e frações. A porcentagem de germinação ajustou-se a uma equação quadrática (Figura $1 \mathrm{E} \mathrm{a} \mathrm{H}$ ), verificandose, conforme as equações, que a germinação, na FAEC e FAEF em alface, não ultrapassou a $70 \%$. Esse fato caracteriza-se pelo efeito inibitório pouco pronunciado nas sementes de alface e cebola submetidas a concentrações dos extratos e frações.

$\mathrm{O}$ processo global da germinação é constituído por três processos parciais: embebição, ativação e crescimento intraseminal. A dificuldade em estabelecer o início e o final do processo faz com que a determinação da germinação seja avaliada por um critério macroscópico: a protrusão da raiz (RANAL et al., 2006). Esse processo é menos sensível aos aleloquímicos do que o crescimento da plântula, mas a quantificação experimental é muito mais simples, pois, para cada semente, o fenômeno é discreto, com a germinação ou não da semente (FERREIRA \& AQUILA, 2000).

As alterações no padrão de germinação podem resultar de diversos efeitos causados em nível primário (GUSMAN et al., 2008). Dentre elas, destacam-se alterações na permeabilidade de membranas, na transcrição e tradução do DNA, na ação de mensageiros secundários, na respiração pelo sequestro do oxigênio, na conformação de enzimas e receptores, ou ainda, pela combinação desses fatores (FERREIRA \& AQUILA, 2000).

Nos resultados de crescimento (Figura 2), verificaram-se, tanto para o comprimento da raiz como do hipocótilo, efeitos negativos ao crescimento na presença da FAEC e FAEF. Os efeitos crescentes com as maiores doses da FAEC e FAEF causam, assim, uma inibição para o comprimento da raiz e hipocótilo. Os efeitos inibitórios mais acentuados foram evidenciados para a concentração de $1.000 \mathrm{mg}$ $\mathrm{L}^{-1}$ da FAEC e FAEF tanto em alface quanto em cebola. Observou-se que a FAEC apresentou maior fitotoxicidade em relação a FAEF, inibindo o crescimento da raiz em $47 \%$ e $37 \%$, do hipocótilo em $82 \%$ e $49 \%$, além de reduzir o acúmulo de massa seca (Figura 3 A a D) em 49\% e 55\% de alface e cebola, respectivamente.

Em trabalho realizado com Croton urucurana, também foi verificado efeito fitotóxico na germinação e crescimento de alface e cebola, sendo observada inibição no crescimento de alface e cebola em $100 \%$, em comparação ao controle, quando submetidas ao óleo volátil do caule de $\boldsymbol{C}$. urucurana (SIMIONATTO et al., 2009).

$\mathrm{O}$ índice mitótico foi continuamente reduzido com o aumento da concentração da FAEC e FAEF de $\boldsymbol{C}$. doctoris (Figura $3 \mathrm{E} \mathrm{a} \mathrm{H}$ ). O maior efeito depressivo foi verificado para a concentração de $1.000 \mathrm{mg} \mathrm{L}^{-1}$ da FAEC, em que o índice mitótico não atingiu mais do que $9,6 \%$ em alface e $46,3 \%$ em cebola. A maior redução no índice mitótico foi verificado em alface, no qual se observou que a concentração de $1.000 \mathrm{mg} \mathrm{L}^{-1}$ da FAEC reduziu em $85 \%$ o índice mitótico de alface, em comparação ao controle.

Nos resultados, observou-se que a FAEC e FAEF apresentaram os maiores efeitos fitotóxicos, verificando-se que o aumento da concentração levou a uma drástica redução do índice mitótico, com paralisação do crescimento radicular, em consequência, principalmente, da ausência da telófase (Tabela 1).

A interferência no crescimento de alface e cebola, na presença da FAEC e FAEF, está associada a uma forte inibição da mitose. Esse fato pode ser atribuído à capacidade dos compostos presentes na FAE em reduzir o índice mitótico, bloqueando parcialmente as fases subsequentes da divisão celular nas maiores concentrações. Mudanças semelhantes 


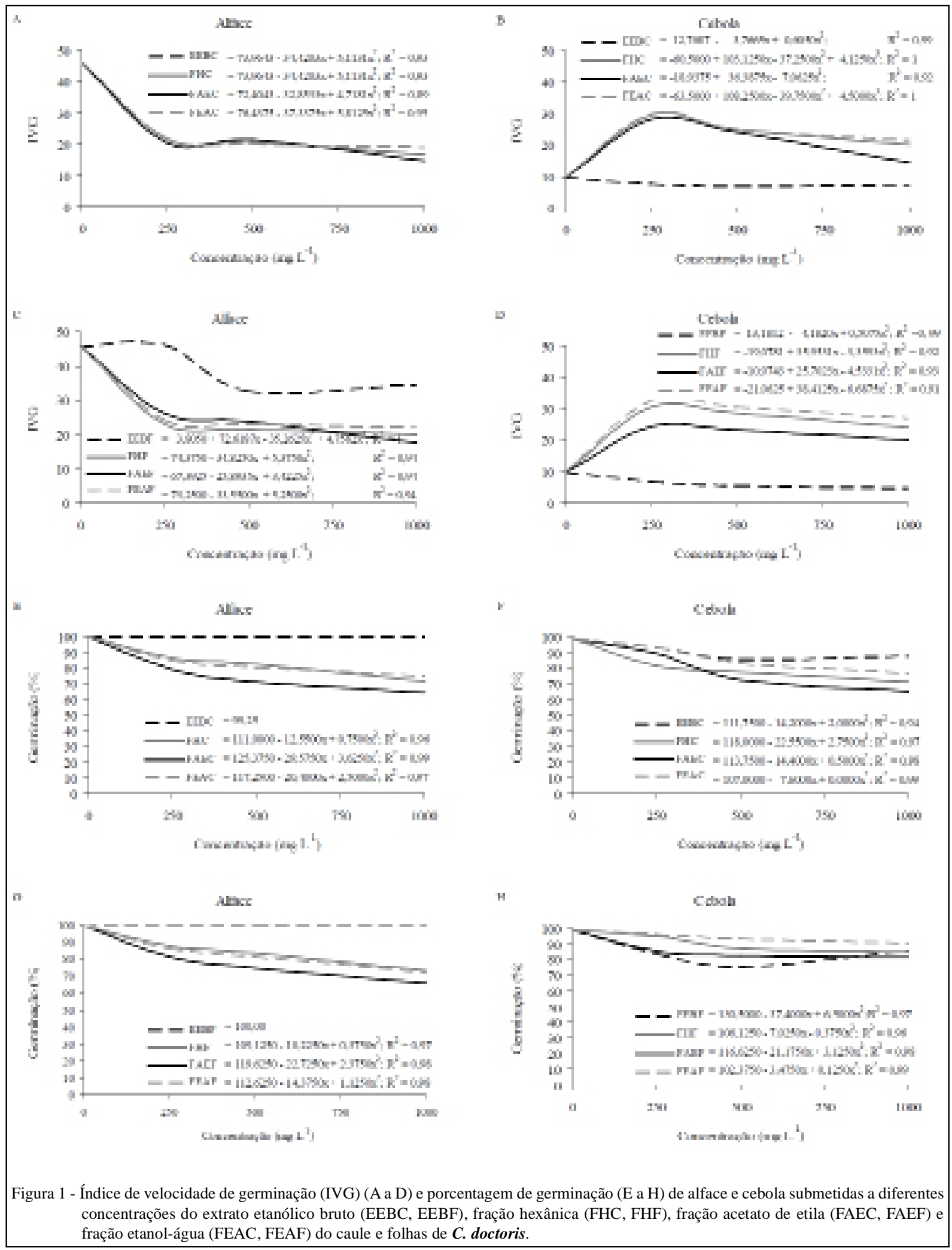

Ciência Rural, v.43, n.4, abr, 2013. 

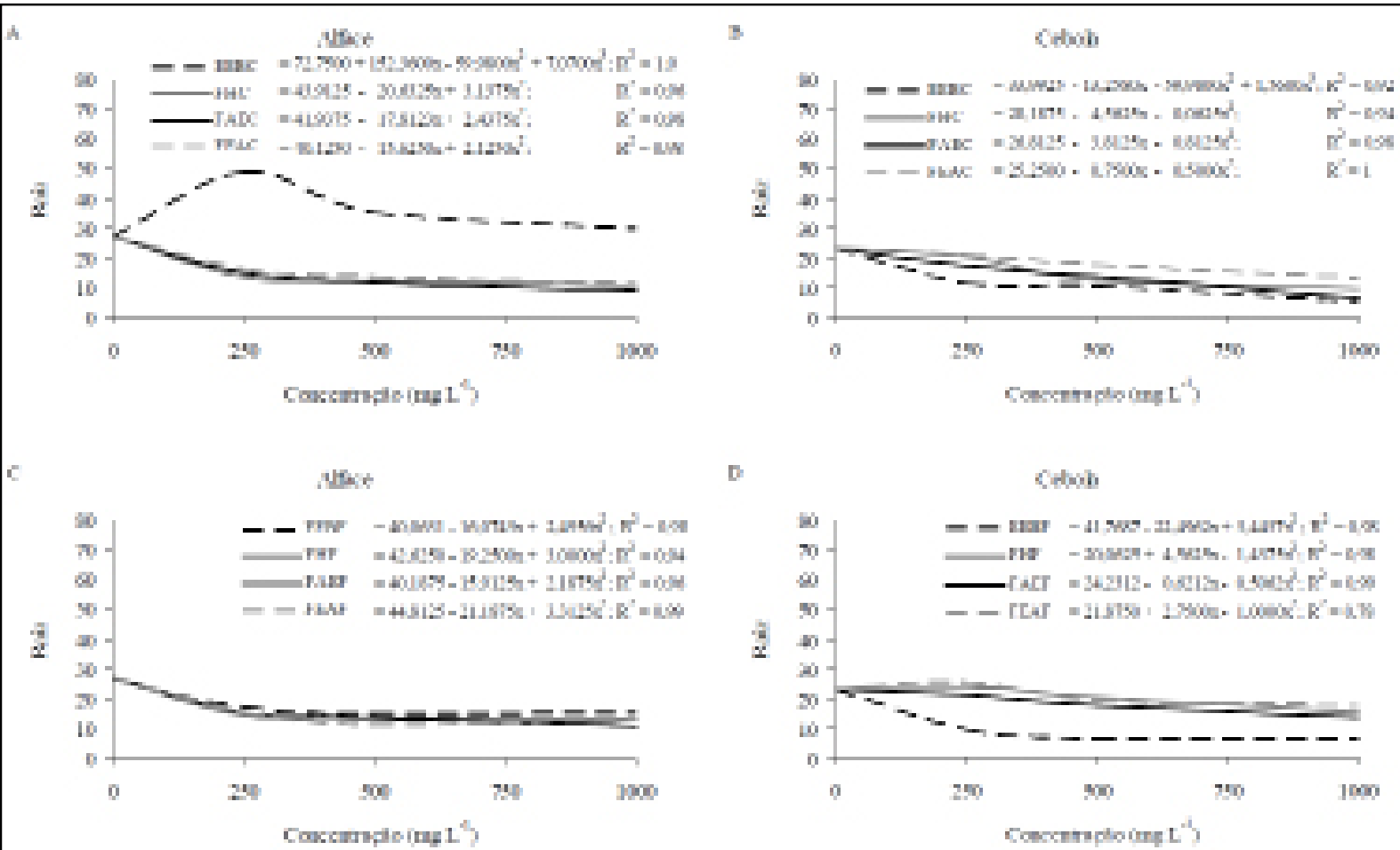

[

Antili

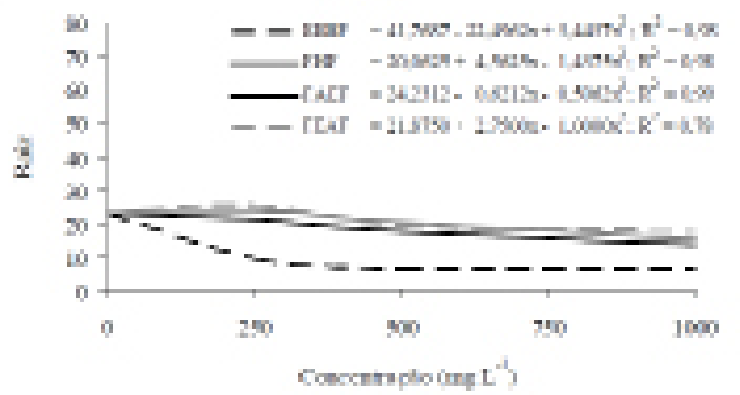

E

F

Enth
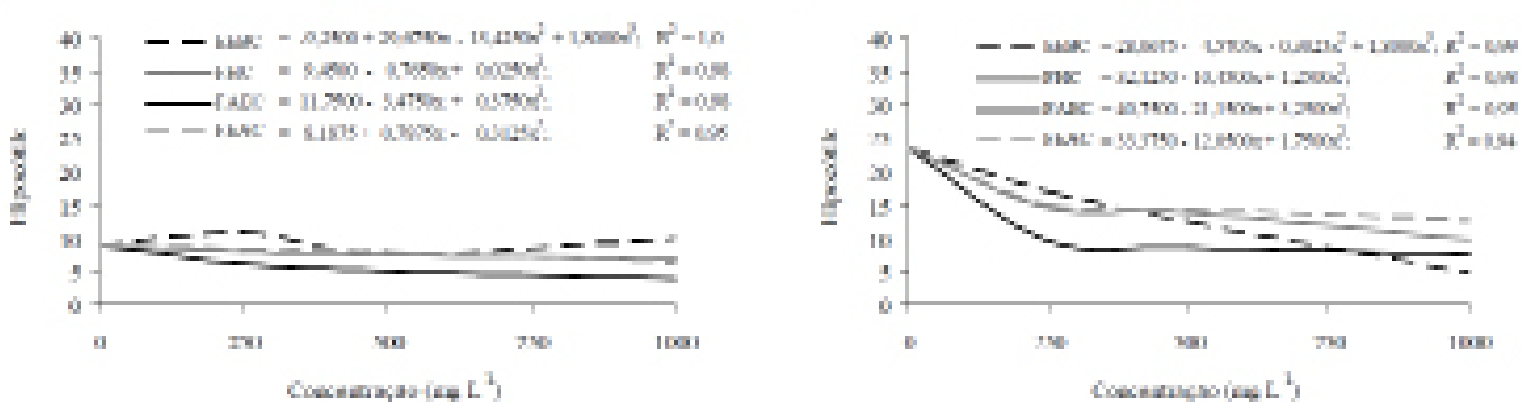

G

M.T.

H

ind
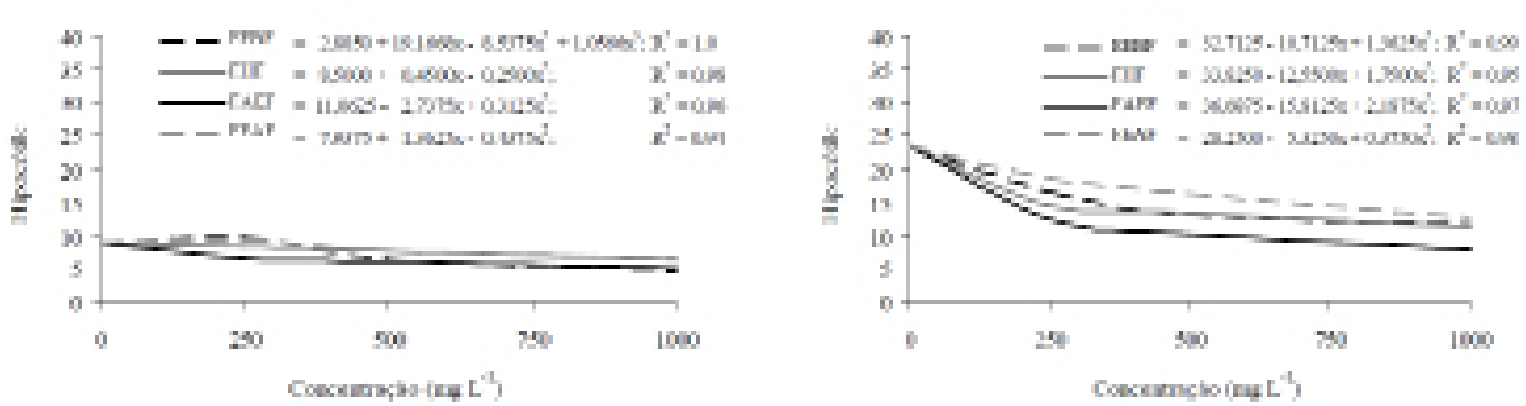

Figura 2 - Comprimento da raiz (A a D) e hipocótilo (E a H) das plântulas de alface e cebola submetidas a diferentes concentrações do extrato etanólico bruto (EEBC, EEBF), fração hexânica (FHC, FHF), fração acetato de etila (FAEC, FAEF) e fração etanol-água (FEAC, FEAF) do caule e folhas de C. doctoris. 


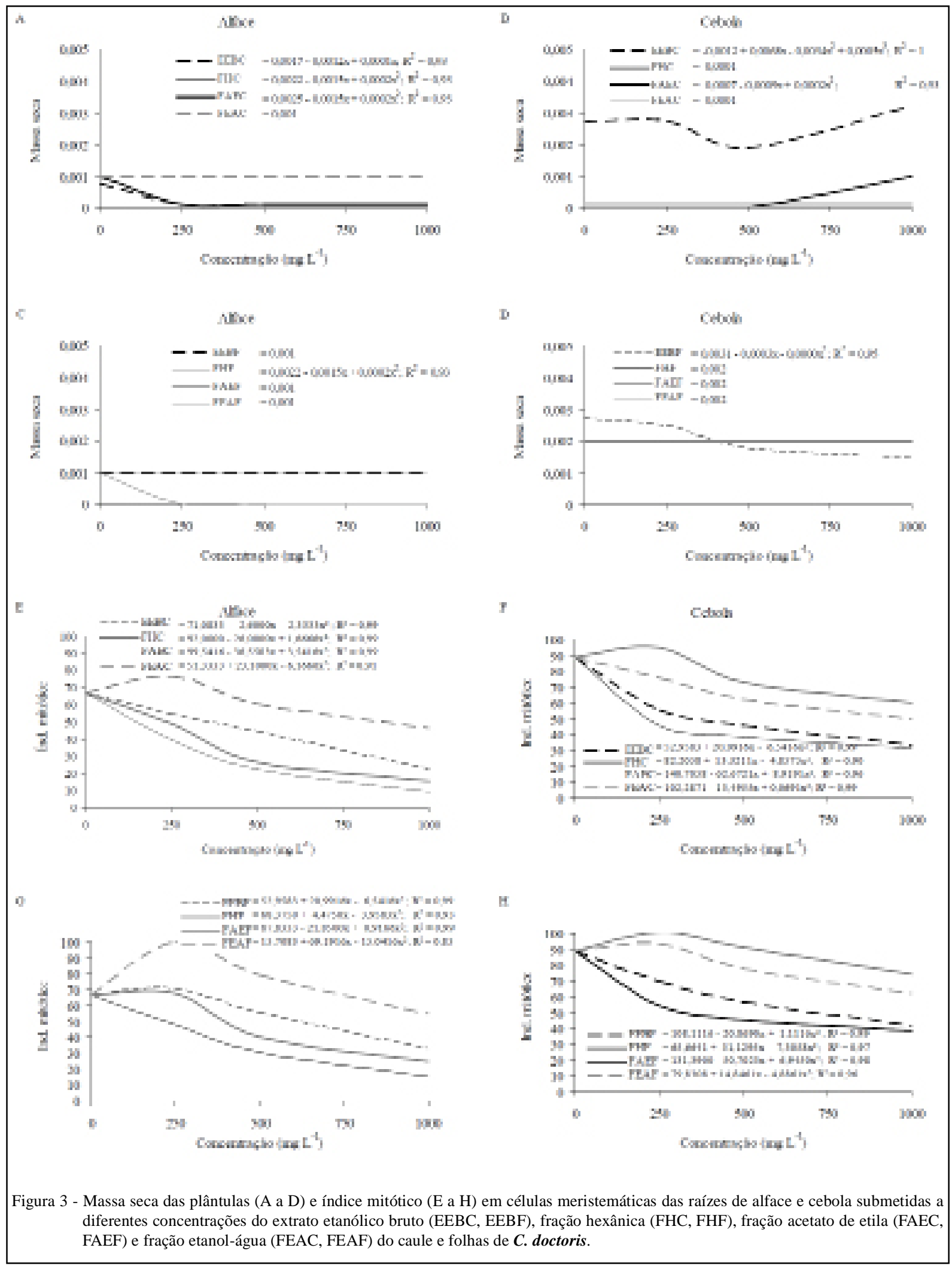

Ciência Rural, v.43, n.4, abr, 2013. 
Tabela 1 - Frequência das diferentes fases da mitose em células meristemáticas das raízes de plântulas de alface e cebola sob diferentes concentrações da fração acetato de etila do caule (FAEC) e das folhas (FAFF) de Croton doctoris.

\begin{tabular}{|c|c|c|c|c|c|}
\hline Concentrações $\left(\mathrm{mg} \mathrm{L}^{-1}\right)$ & Número de células em mitose & Prófase & Metáfase & Anáfase & Telófase \\
\hline 0 & $133,7^{\mathrm{a}}$ & $82,3 a$ & $25,0 \mathrm{a}$ & $18,7 \mathrm{a}$ & $7,7 \mathbf{a}$ \\
\hline 250 & $79,3 b$ & $69,7 \mathrm{~b}$ & $8,0 \mathrm{~b}$ & $3,3 b$ & $0,0 \mathrm{~b}$ \\
\hline 500 & $45,3 b$ & $37,3 b$ & $4,7 \mathrm{~b}$ & $1,7 \mathrm{~b}$ & $0,0 \mathrm{~b}$ \\
\hline 1000 & $19,3 b$ & $18,7 \mathrm{~b}$ & $0,7 \mathrm{~b}$ & $0,0 \mathrm{~b}$ & $0,0 \mathrm{~b}$ \\
\hline 0 & $266,3^{a}$ & $159,3 \mathbf{a}$ & $63,0 \mathrm{a}$ & $34,0 \mathrm{a}$ & $10,0 \mathrm{a}$ \\
\hline 250 & $136,7 \mathrm{~b}$ & $69,7 \mathrm{~b}$ & $56,3 b$ & $10,7 \mathrm{~b}$ & $0,0 \mathrm{~b}$ \\
\hline 500 & $115,3 b$ & $64,7 \mathrm{~b}$ & $42,3 b$ & $8,3 b$ & $0,0 \mathrm{~b}$ \\
\hline 1000 & $92,7 \mathrm{~b}$ & $53,0 \mathrm{~b}$ & $36,0 \mathrm{~b}$ & $3,7 \mathrm{~b}$ & $0,0 \mathrm{~b}$ \\
\hline \multicolumn{6}{|c|}{ - } \\
\hline Concentrações $\left(\mathrm{mg} \mathrm{L}^{-1}\right)$ & Número de células em mitose & Prófase & Metáfase & Anáfase & Telófase \\
\hline 0 & $133,7 \mathrm{a}$ & $82,3 \mathbf{a}$ & $25,0 \mathrm{a}$ & $18,7 \mathrm{a}$ & $7,7 \mathrm{a}$ \\
\hline 250 & $96,0 \mathrm{~b}$ & $75,3 b$ & $13,3 b$ & $6,3 b$ & $2,0 \mathrm{~b}$ \\
\hline 500 & $60,7 \mathrm{~b}$ & $48,33 b$ & $6,0 \mathrm{~b}$ & $4,3 b$ & $1,0 \mathrm{~b}$ \\
\hline 1000 & $30,3 b$ & $28,0 \mathrm{~b}$ & $1,3 b$ & $0,3 b$ & $0,7 \mathrm{~b}$ \\
\hline 0 & $266,3 a$ & $159,3 \mathrm{a}$ & $66,3 a$ & $34,0 \mathbf{a}$ & $10,0 \mathrm{a}$ \\
\hline 250 & $163,0 \mathrm{~b}$ & $79,3 \mathrm{~b}$ & $63,0 \mathrm{~b}$ & $16,7 \mathrm{~b}$ & $0,7 \mathrm{~b}$ \\
\hline 500 & $135,7 \mathrm{~b}$ & $71,3 b$ & $53,3 b$ & $10,7 \mathrm{~b}$ & $0,3 b$ \\
\hline 1000 & $115,7 \mathrm{~b}$ & $64,0 \mathrm{~b}$ & $43,7 \mathrm{~b}$ & $8,0 \mathrm{~b}$ & $0,0 \mathrm{~b}$ \\
\hline
\end{tabular}

Médias seguidas de mesma letra do controle não diferem entre si pelo teste de Dunnet a $5 \%$ de probabilidade

foram observadas nas cromátides das células de $\boldsymbol{A}$. cepa, submetidas ao extrato aquoso de Taxus baccata (MAJEWSKA et al., 2000).

Essa interferência na divisão celular causada pela ação das substâncias químicas contidas na FAEC com acentuado efeito sobre a morfologia do sistema radicular provavelmente representa um dos mecanismos de ação das substâncias (s) com atividade fitotóxica. A redução do crescimento de plantas na presença de aleloquímicos é associada com uma forte inibição da mitose e/ou rompimento da estrutura das organelas, como, por exemplo, núcleo e mitocôndrias (GNIAZDOWSKA e BOGATEK, 2005). O uso do extrato aquoso das folhas da leucena (Leucaena leucocephala) reduziu o índice mitótico em plantas de milho, bloqueando completamente a fase de telófase em maiores concentrações (PIRES et al., 2001), fato também observado nos resultados da FAEC do presente trabalho.
FERNANDES et al. (2009) afirmam que o herbicida trifluralina age sobre o desenvolvimento da planta, promovendo redução no índice mitótico de células meristemáticas de Allium cepa, o que leva ao comprometimento no crescimento do organismo.

No bioensaio, percebe-se que o crescimento das plântulas foi mais sensível aos tratamentos do que a germinação. Isso se deve à absorção e, consequentemente, à concentração de fitotoxinas nos tecidos radiculares ser favorecida, devido ao contato físico da raiz com o papel-filtro, o que a expôs diretamente ao extrato. A capacidade de translocação do aleloquímico da raiz para a parte aérea e o mecanismo de ação dele também devem ser considerados. O sítio de ação do fitoquímico pode não estar relacionado à inibição da divisão celular do eixo embrionário, resultando na ausência de efeito sobre a germinação de sementes. Dessa forma, a bioatividade de extratos estaria condicionada à capacidade de 
absorção, translocação e mecanismo de ação dos seus compostos potencialmente alelopáticos (CORREIA et al., 2005).

Os resultados obtidos no presente trabalho evidenciam que a FAE de $\boldsymbol{C}$. doctoris apresentam ação inibitória sobre o crescimento e divisão celular das plantas-alvo, interferindo no crescimento, multiplicação e manutenção das células, por interferir na divisão celular, sendo esses processos cruciais para o estabelecimento de qualquer planta.

\section{CONCLUSÃO}

Os aleloquímicos presentes na FAE do caule e folhas de $\boldsymbol{C}$. doctoris causam inibição no crescimento de alface e cebola. Um dos mecanismos de ação na inibição do crescimento provavelmente é a ação inibitória da FAE na etapa de divisão celular das plantas alvo. Esses resultados sugerem o alto potencial fitotóxico da espécie $\boldsymbol{C}$. doctoris, porém são necessários testes para avaliar a fitotoxicidade em outras espécies alvo, além de isolar e identificar o composto com atividade fitotóxica.

\section{REFERÊNCIAS}

BARBOSA, B.C.A. et al. Síntese e avaliação da atividade fitotóxica de lactonas derivadas do 2,4,-dimetil-8-oxabiciclo[3,2,1.]-oct-6em-3-ona. Química Nova, v.25, p.203-208, 2002. Disponível em: <http://dx.doi.org/10.1590/S0100-40422002000200006>. Acesso em: 30 ago. 2011. doi: 10.1590/S0100-40422002000200006.

BRASIL. Ministério da Agricultura e Reforma Agrária. Regras para a Análise de Sementes. Brasília: SNDA/DNDU/CLU, 2009. 365p.

CORREIA, N.M. et al. Influência de extratos aquosos de sorgo sobre a germinação e desenvolvimento de plantas de soja. Ciência Rural, v.35, n.3, p.498-503, 2005. Disponível em: <http://dx.doi. org/10.1590/S0103-84782005000300002>. Acesso em: 27 mar. 2012. doi: $10.1590 / \mathrm{S} 0103-84782005000300002$.

DAYAN, F.E. et al. Investigating the mode of action of natural phytotoxins. Journal of Chemical Ecology, v.26, n.9, p.20792093, 2000.
FERREIRA, A.G.; AQUILA, M.E.A. Alelopatia: uma área emergente da ecofisiologia. Revista Brasileira de Fisiologia Vegetal, v.12, p. 175-204, 2000.

FERNANDES, T.C.C. et al. Origin of nuclear and chromosomal alterations derived from the action of an aneugenic agentTrifluralinherbicide. Ecotoxicology Environmental Safety, v.72, p.1680-1686, 2009.

GNIAZDOWSKA, A.; BOGATEK, R. Allelopathic interactions between plants. Multisite action of allelochemicals. Acta Physiology Plant, v.27, n.3, p.395-407, 2005.

GUSMAN, G.S. et al. Alelopatia de Baccharis dracunculifolia DC. sobre a germinação e desenvolvimento de espécies cultivadas. Acta Scientiarum Biological Science, v.30, p.119125, 2008. Disponível em: <http://eduemojs.uem.br/ojs/index. php/ActaSciBiolSci/article/view/3592>. Acesso em: 15 dez. 2011. doi: 10.4025/actascibiolsci.v30i2.3592.

MACIAS, F.A. et al. Sesquiterpene lactones with potencial use as natural herbicides models. 2. Guaianolides. Journal of Agricultural and Food Chemistry, v.48, p.5288-5296, 2000a.

MACIAS, F.A. et al. Search for a standart phytotoxic biossay for allelochemicals. Selection of standard target species. Journal Agricultural and Food Chemistry, v.48, n.6, p.2512-2521, 2000b.

PIRES, N.M. et al. Efeito do extrato aquoso de leucena sobre o desenvolvimento, índice mitótico e atividade da peroxidase em plântulas de milho. Revista Brasileira de Fisiologia Vegetal, v.13, n.1, p.55-65, 2001

POTT, A. et al. Plantas daninhas de pastagem da região dos Cerrados. Campo Grande: Embrapa Gado de Corte. 2007. 336p.

MAJEWSKA,A.M. et al. Influence of extracts from shoots of Taxus baccata var. elegantissima on mitotic activity of meristematic cells of Allium cepa L. roots. Acta Societatis Botanicorum Poloniae, v.69. p.185-192, 2000

RANAL, M.A.; SANTANA, D.G. How and why to measure the germination process? Revista Brasileira de Botânica, v.29, p.111, 2006.

RIZVI, S.J.H. et al. Allelopatic interactions in agroforestry systems. Critical Reviews in Plant Sciences, v.18, p.773-796, 1999.

SALATINO, A. et al. Traditional uses, chemistry and pharmacology of Croton species (Euphorbiaceae). Journal Brazilian Chemical Society, v.18, n.1, p.11-33, 2007.

SIMIONATTO, E. et al. Bioactivity and chemical composition of the essential oils of Croton urucurana Baillon (Euphorbiaceae). Journal of Essential Oil-Bearing Plants, v.12, p.250-261, 2009. 